\title{
ИЗМЕНЕНИЕ АГРОХИМИЧЕСКИХ СВОЙСТВ ТЕМНО-СЕРОЙ ПОЧВЫ ЗАПАДНОЙ ЛЕСОСТЕПИ УКРАИНЫ ПОД ВЛИЯНИЕМ ДЛИТЕЛЬНОГО СЕЛЬСКОХОЗЯЙСТВЕННОГО ИСПОЛЬЗОВАНИЯ
}

\author{
(С) 2014 г. С. И. Веремеенко, О. А. Фурманец \\ Национальный университет водного хозяйства и природопользования, \\ 33018, Ровно, ул. Соборная, 11 \\ e-mail:Oleg_Kisss@mail.ru \\ Поступила в редакцию 15.01.2013 г.
}

\begin{abstract}
Изучены изменения свойств темно-серой лесной почвы на территории Западной Лесостепи Украины под влиянием длительного сельскохозяйственного использования в зернопропашном севообороте без применения удобрений, а также на вариантах с применением минеральных и комплексного органо-минерального удобрений. На основе использования комплекса методов установлены изменения морфологических признаков почвы, показателей реакции почвенной среды, гидролитической и обменной кислотности, суммы поглощенных оснований, степени насыщения основаниями, содержания и запасов органического углерода на протяжении 50-летнего периода распашки. Установлено, что в течении исследуемого периода (1961-2010 гг.) в почвах интенсифицировались процессы подкисления верхних слоев, уменьшения содержания органических веществ, степени насыщенности основаниями. Исследовано влияние системы хозяйствования на направление и динамику деградационных процессов в почвенной среде. Возделывание почв без применения удобрений вызывало уменьшение содержания гумуса, применение минеральных удобрений провоцировало увеличение их кислотности.
\end{abstract}

Ключевые слова: интенсивное использование почв, система удобрения, реакция почвенного раствора, деградация почв.

DOI: $10.7868 / \mathrm{S} 0032180 \mathrm{X} 14050244$

\section{ВВЕДЕНИЕ}

С середины XX в. интенсивность техногенной и энергетической нагрузки на пахотные почвы начала резко возрастать. В условиях административной плановой экономической системы хозяйствования преобладали системы земледелия, при которых наблюдалось усиление антропогенной нагрузки на агроценозы [16, 21].

Антропогенное использование почв вызывает изменение их химических, физических, агрохимических и морфологических свойств на всех уровнях организации почвенного профиля [8]. Такие изменения позволяют проследить ускоренную эволюцию почв [22].

Около 25\% сельскохозяйственных земель Европы имеют пониженную производительность, из них около $7.7 \%$ - вследствие агрохимической деградации, при этом темпы их ухудшения существенно ускорились в последние 50 лет [24, 25].

$\mathrm{K}$ негативным проявлениям агрохимической деградации земель следует отнести дисбаланс пи- тательных элементов, ухудшение физических свойств, повышение кислотности или подщелачивание, дегумификацию, засоление, вымывание микро- и макроэлементов, переход элементов питания в труднодоступные формы [23].

Наиболее быстро в пахотных почвах происходят изменения агрофизических свойств - уплотнение пахотного и подпахотного слоев, вследствие чего меняется строение порового пространства и водопроницаемость. Усиление антропогенной нагрузки на почвы (в частности, на серые лесные) может провоцировать их агрохимическую деградацию - увеличение кислотности пахотного слоя, изменение состава поглощенных катионов и степени насыщенности основаниями, дегумификацию. Интенсивность и направленность процессов деградации находятся в прямой зависимости от степени и длительности антропогенного воздействия $[9,19,22]$.

Длительный период сельскохозяйственного использования преобладающей части территорий Лесостепи Украины с сильной техногенной на- 
грузкой привел к значительным изменениям состава, свойств и режимов пахотных почв [3]. Среди факторов антропогенного воздействия на почвенный покров внесение удобрений - один из наиболее значимых. Удобрения также оказывают влияние на агроэкологическое состояние и свойства пахотных почв и создают дополнительное, часто труднопрогнозируемое давление на агроэкосистему в целом. Интенсификация технологий выращивания сопровождается ростом урожайности, что приводит к усилению выноса питательных элементов из почвы, и, как следствие, их отрицательному балансу в севообороте, что особенно актуально при разомкнутом цикле агропроизводства.

Ранее эта проблема решалась путем постоянного, часто несбалансированного и научно необоснованного увеличения норм удобрений и усиления химизации, что привело к необратимым изменениям в почвенной среде. К агроэкологическим последствиям длительного применения минеральных и органических удобрений относят ухудшение агрохимических, физико-химических и других свойств удобряемых почв. Большая часть минеральных удобрений является физиологически кислыми, поэтому их длительное применение в высоких нормах часто сопровождается подкислением почв [12].

Согласно исследованиям Филона с соавт. [20] многолетнее внесение минеральных удобрений приводит к увеличению обменной и гидролитической кислотности, уменьшению степени насыщенности темно-серой почвы основаниями. Такие негативные процессы на пахотных землях при систематическом и длительном применении удобрений предопределяются не только физиологической кислотностью последних, но и интенсификацией выноса биофильных элементов из почвы (в том числе кальция и магния) вследствие увеличения урожайности культур. Применение минеральной системы удобрений ведет к разрушению структуры, увеличениют плотности сложения почвы, уменьшению их пористости [15]. Длительное производственное использование почв без внесения органических удобрений приводит также к уменьшению содержания гумуса, или, в лучшем случае, позволяет поддерживать его исходный уровень [11].

По утверждению ряда авторов [10, 11, 14] негативное влияние минеральных удобрений на физико-химические показатели почвы можно компенсировать внесением органических удобрений. Это является важной мерой предотвращения процесса дегумификации почв. Все системы удобрения можно ранжировать по эффективности к восстановлению запасов гумуса: минеральная-органическая-органо-минеральная [10]. Вместе с тем, среди факторов антропогенного воздействия, влияющих на гумусовое состояние почв, удобрения являются одним из наиболее весомых [13].

Современное экономическое состояние страны наложило дополнительный отпечаток на агроэкологическое состояние почв. Общие тенденции к уменьшению объемов развития животноводства и сокращению поголовья крупного рогатого скота, которые наблюдались начиная со второй половины 90-х гг., в последние годы достигли катастрофических масштабов. Упадок или полная ликвидация мощных животноводческих комплексов привели к резкому уменьшению объемов внесения органических удобрений в севооборотах.

Недостаток финансовых ресурсов у одних землепользователей и небрежное отношение к почвам других, привели к общему сокращению объемов химических мелиораций, в частности, к проведению известкования кислых почв.

В результате такого состояния отрасли, проблемы агрохимической и физико-химической деградации почв еще более обострились, а исследования, связанные с экологией и экономикой применения удобрений приобрели еще большую актуальность.

\section{ОБЪЕКТ И МЕТОДЫ}

Исследования проводились на территории Ровенской обл., изучаемые почвы - темно-серые оподзоленные легкосуглинистые, типичные для Западной Лесостепи Украины. Полевые наблюдения проводились на территории многолетнего полевого стационара Института сельского хозяйства Западного Полесья Украины. Лабораторные исследования - на базе кафедры агрохимии, почвоведения и земледелия Национального университета водного хозяйства и природопользования.

Полевой стационар заложен в 1961 г., исходное состояние почвы было зафиксировано закладкой 12 основных почвенных разрезов с отбором образцов и последующим определением физических, водно-физических и агрохимических свойств. Также с помощью серии вспомогательных разрезов была проведена почвенная съемка всей территории стационара с построением детальных почвенных карт.

Начиная с 1961 г., на территории стационара заложен многолетний опыт с зернопропашным севооборотом, период ротации - 9 лет. В полевом опыте применялась развернутая схема с удобрениями, включающая следующие варианты: 1 контроль (без удобрений); 2 - минеральная система удобрений N72P64K65; 3 - органо-минеральная система удобрений 10 т/га навоза + + N72P64K65.

Программой исследований на стационаре было предусмотрено постоянное проведение агро- 


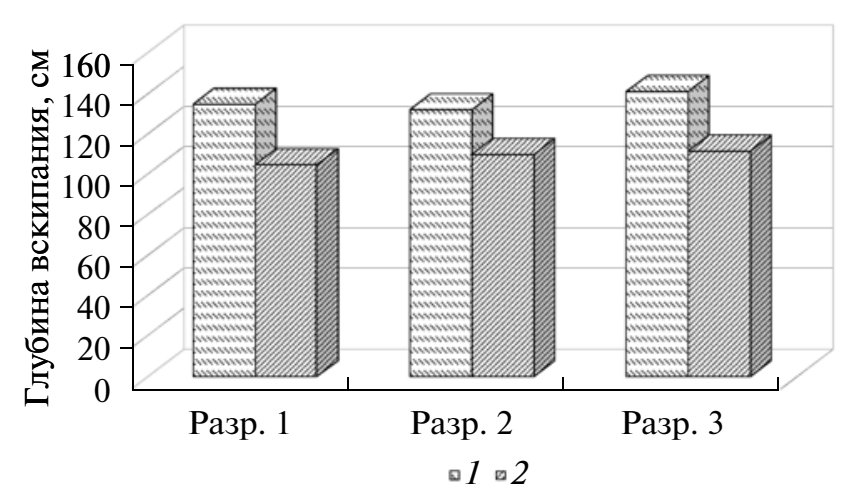

Рис. 1. Изменение глубины вскипания карбонатов в темно-серой оподзоленной почве в 1961 (1) и 2010 (2) гг.

химических, фенологических, а также метеорологических наблюдений.

Для последующих исследований почв стационара нами было выбрано три варианта - контроль (без внесения удобрений на протяжении всего периода), минеральная и органо-минеральная системы удобрений [13].

В 2010 г. на всех трех вариантах были повторно заложены почвенные разрезы, которые пространственно соответствовали площадкам закладки исходных разрезов 1961 г.

Агрохимические исследования проводились следующими методами: реакция почвенного раствора потенциометрически, гидролитическая и обменная кислотность - по Каппену, степень насыщения основаниями - по Каппену-Гильковицу, содержание органического углерода - по Тюрину.

Цель работы - изучение влияния длительного сельскохозяйственного использования темно-серой почвы в различных системах удобрения на изменение ее агрохимических и физико-химических показателей в контексте общих изменений почвенно-климатических условий территории.

\section{РЕЗУЛЬТАТЫ ИССЛЕДОВАНИЙ}

Исследование почвенных разрезов на вариантах полевого стационара показало, что в почвах отображаются признаки как дернового (хорошо развитый гумусовый горизонт, наличие кротовин и карбонатных журавчиков), так и подзолистого (выщелоченность карбонатов из верхних горизонтов, перемещение коллоидов в нижние слои, что привело к дифференциации почвенного профиля на элювиальный и иллювиальный горизонты) типов почвообразования.

Общее строение профилей почв следующее (по состоянию на ноябрь 2010 г., глубины горизонтов усреднены):
А пах $(0-35$ см $)$ - пахотный гумусовый горизонт, образован перемешиванием исходного гор. A1A2 с частичным разрушением структуры и последующим уплотнением вследствие механического воздействия - гумусово-элювиальный, темно-серый, безкарбонатный, рыхлый в верхней части и уплотненный в нижней, структура комковатая, в нижней части заметна присыпка $\mathrm{SiO}_{2}$, переход заметен;

А2В (35-78 см) - серый с хорошо выраженным буроватым оттенком, уплотненный, структура комковато-ореховатая, много присыпки $\mathrm{SiO}_{2}$, переход четко выраженный;

B1 (78-133 см) - бурый с палевым оттенком, неоднороден, хорошо уплотнен, структура призматическая, встречаются кротовины, переход постепенный;

B2Ck (133-159 см) - палевый с буроватым оттенком, не плотный, структура призматическая, влажный, встречаются карбонатные включения, вскипание от кислоты, переход к материнской породе постепенный;

Ck (>159 см) - материнская порода, влажный карбонатный лёсс.

Описание показало, что по отдельным вариантами исследования существенных изменений в генетическом строении почвы не произошло, за исключением трансформации исходного гор. А1А2 в пахотный (табл. 1). Проведя сопоставление исходного почвенного разреза 1961 г. и разреза 2010 г., следует отметить перемещение вверх по профилю карбонатов (рис. 1). Это явление, вероятно, связано с повышением среднего уровня грунтовых вод за указанный период. Согласно исходным описаниям почвы перед закладкой полевого стационарного опыта, ни в одном из разрезов до глубины двух метров не было воды или признаков подтопления. В то время как во всех трех разрезах 2010 г. на глубине 170-180 см материнская порода очень влажная, и глубже двух метров заметны признаки переувлажнения. В свою очередь, такое повышение уровня грунтовых вод, вероятно, вызвано увеличением годового количества осадков, которое наблюдается на протяжении последних лет [4, 5]. В связи с близким залеганием вод, в нижней части почвенного профиля преобладали восходящие потоки влаги, что способствовало перемещению вверх карбонатов кальция.

Перед закладкой полевого опыта почва имела слабокислую реакцию в верхних горизонтах (рН 5.38-5.50 для верхнего слоя; 5.54-5.61 для гор. А2В), постепенно переходящую с глубиной в нейтральную.

Гидролитическая кислотность гор. А1А2 колебалась в пределах 2.68-2.75 смоль(экв)/кг, резко уменьшаясь вниз по профилю, степень насыщенности основаниями увеличивалась от 76.0-76.7\% 
Таблица 1. Глубина залегания нижней границы генетических горизонтов в исследованных почвах, см (над чертой - среднее значение; под чертой - интервал изменения величины)

\begin{tabular}{|c|c|c|c|c|c|}
\hline \multirow{2}{*}{ Разрез } & \multicolumn{5}{|c|}{ Генетический горизонт } \\
\hline & A1A2/A пах & $\mathrm{A} 2 \mathrm{~B}$ & $\mathrm{~B} 1$ & $\mathrm{~B} 2 \mathrm{Ck}$ & $\mathrm{Ck}$ \\
\hline \multicolumn{6}{|c|}{ Исходная почва, 1961 г. } \\
\hline 1 & $\frac{35.2 \pm 0.19}{35.0-35.5}$ & $\frac{70.2 \pm 0.45}{69.5-70.7}$ & $\frac{130.4 \pm 0.38}{130.0-131.0}$ & $\frac{150.5 \pm 0.36}{150.0-151.0}$ & $\frac{>150.5}{150.0-151.0}$ \\
\hline 2 & $\frac{33.7 \pm 0.51}{33.1-34.5}$ & $\frac{68.4 \pm 0.19}{68.2-68.7}$ & $\frac{127.3 \pm 0.34}{127.0-127.9}$ & $\frac{147.3 \pm 0.35}{146.9-147.9}$ & $\frac{>147.3}{146.9-147.9}$ \\
\hline 3 & $\frac{36.9 \pm 0.56}{36.5-37.5}$ & $\frac{71.6 \pm 0.54}{70.6-72.2}$ & $\frac{130.6 \pm 0.41}{129.5-131.0}$ & $\frac{151.0 \pm 0.53}{150.5-152.0}$ & $\frac{>151.0}{150.5-152.0}$ \\
\hline \multicolumn{6}{|c|}{2010 г. } \\
\hline 1 & $\frac{33.4 \pm 0.36}{33.0-34.0}$ & $\frac{72.0 \pm 0.56}{71.0-72.7}$ & $\frac{130.3 \pm 0.53}{130.0-131.0}$ & $\frac{150.4 \pm 0.49}{150.0-151.0}$ & $\frac{>150.4}{150.0-151.0}$ \\
\hline 2 & $\frac{34.2 \pm 0.54}{33.6-34.9}$ & $\frac{81.7 \pm 0.38}{81.3-82.4}$ & $\frac{135.2 \pm 0.41}{134.7-135.9}$ & $\frac{168.3 \pm 0.36}{167.8-168.9}$ & $\frac{>168.3}{167.8-168.9}$ \\
\hline 3 & $\frac{37.4 \pm 0.29}{37.0-37.8}$ & $\frac{80.4 \pm 0.37}{80.0-81.0}$ & $\frac{134.5 \pm 0.44}{134.0-135.2}$ & $\frac{160.4 \pm 0.37}{160.0-161.0}$ & $\frac{>160.4}{160.0-161.0}$ \\
\hline
\end{tabular}

Примечание. Разр. 1 - вариант без применения удобрений, разр. 2 - вариант с применением минеральных удобрений, разр. 3 - вариант с органо-минеральной системой удобрения.

в верхнем слое до 93-93.5\%. Содержание органического углерода для гор. А1А2 $1.75-1.79 \%$, также резко уменьшается с глубиной.

На момент закладки многолетнего опыта пространственная вариация исследуемых показателей между разрезами статистически незначима (табл. 2).

Анализируя изменение свойств темно-серой почвы за период 1961-2010 гг., следует отметить изменение показателей, касающихся реакции почвенного раствора.

Так, в исходной почве 1961 г., $\mathrm{pH}$ солевой вытяжки изменялся от 5.4 (в верхнем гумусовом горизонте) до 7.0 на глубине 2 м (табл. 3). При этом переход от слабокислой реакции среды к нейтральной примерно совпадал с глубиной вскипания карбонатов (120-130 см). В течение всего исследуемого периода наблюдается тенденция к подкислению верхнего пахотного слоя почвы. Так уже в 1972 г. значение $\mathrm{pH}$ составляло 5.3 единицы, в 2001 г. - 4.6 единицы, а в 2010 г. - 4.5. Однако указанная закономерность справедлива лишь для верхнего (0-30 см) слоя почвы, в более глубоких горизонтах - зависимость обратная. Так, значение $\mathrm{pH}$ солевой вытяжки карбонатных горизонтов менялось от 6.9-7.0 (1961 г.) до 7.3-7.4 (2010 г.). Реакция солевой вытяжки подпахотного гор. А2В также изменялась на протяжении периода наблюдений - в течение первой ротации полевого севооборота наблюдалось увеличение значения пока- зателя от 5.5 до 5.8 единиц, в последующие годы колебание в пределах 5.1-5.4.

В течение всего периода исследований также отмечается тенденция к увеличению гидролитической кислотности верхней части почвы (табл. 3). В пахотном горизонте значение этого показателя возрастает от 2.75 (1961 г.) до 5.59 смоль(эКв)/кг (2010 г.). Аналогичное явление можно наблюдать и в нижних некарбонатных слоях почвы.

Состав обменных катионов в разных типах почв изменяется в широких пределах, он обусловлен типом почвообразования, химическим составом почвообразующих пород, и его корректируют в процессе окультуривания и активного антропогенного использования. Для темно-серых почв лесостепной зоны Украины в целом характерна высокая насышенность почвенного профиля кальцием и магнием, однако в условиях промывного типа водного режима и подкисления почвенного раствора в составе обменных катионов возрастает доля ионов водорода и алюминия, что ярко иллюстрируется увеличением значений гидролитической кислотности. Вместе с тем, следует отметить увеличение общего количества поглощенных оснований, особенно заметное в нижних горизонтах. Возможно, это обусловлено одновременным сочетанием двух процессов - активного промывания профиля почвы осадками, что способствует перемещению карбонатов вниз, и их поднятием капиллярными силами за счет повышения уровня грунтовых вод. 
Таблица 2. Характеристика исходных разрезов, 1961 г.

\begin{tabular}{|c|c|c|c|c|c|c|c|}
\hline \multirow[t]{2}{*}{ Разрез } & \multirow[t]{2}{*}{ Горизонт } & \multirow[t]{2}{*}{ Глубина, см } & \multirow[t]{2}{*}{$\begin{array}{c}\text { рН солевой } \\
\text { вытяжки }\end{array}$} & Н гидр & $\begin{array}{c}\text { Сумма } \\
\text { поглощенных } \\
\text { оснований }\end{array}$ & $\begin{array}{c}\text { Степень } \\
\text { насыщенности } \\
\text { основаниями }\end{array}$ & С орг \\
\hline & & & & \multicolumn{2}{|c|}{ смоль(эКв)/Кг } & \multicolumn{2}{|l|}{$\%$} \\
\hline \multirow[t]{5}{*}{1} & A1A2 & $0-35$ & 5.42 & 2.75 & 8.71 & 76.0 & 1.79 \\
\hline & A2B & $36-70$ & 5.54 & 1.25 & 10.89 & 89.7 & 0.71 \\
\hline & B1 & $71-130$ & 5.73 & 0.68 & 9.70 & 93.5 & 0.48 \\
\hline & $\mathrm{B} 2 \mathrm{CK}_{\mathrm{K}}$ & $131-150$ & 6.94 & 0.11 & - & - & 0.28 \\
\hline & $\mathrm{CK}_{\mathrm{K}}$ & $>150$ & 7.01 & - & - & - & - \\
\hline \multirow[t]{5}{*}{2} & A1A2 & $0-33$ & 5.38 & 2.69 & 8.60 & 76.2 & 1.76 \\
\hline & A2B & $34-68$ & 5.61 & 1.17 & 10.88 & 90.3 & 0.69 \\
\hline & B1 & $69-127$ & 5.85 & 0.72 & 9.89 & 93.2 & 0.43 \\
\hline & $\mathrm{B} 2 \mathrm{CK}_{\mathrm{K}}$ & $128-147$ & 7.03 & 0.08 & - & - & 0.24 \\
\hline & $\mathrm{CK}_{\mathrm{K}}$ & $>147$ & 7.13 & - & - & - & - \\
\hline \multirow[t]{5}{*}{3} & A1A2 & $0-36$ & 5.50 & 2.68 & 8.78 & 76.7 & 1.75 \\
\hline & A2B & $37-71$ & 5.59 & 1.15 & 10.69 & 90.3 & 0.74 \\
\hline & B1 & $72-130$ & 5.84 & 0.75 & 9.82 & 92.9 & 0.41 \\
\hline & $\mathrm{B} 2 \mathrm{CK}_{\mathrm{K}}$ & $131-151$ & 7.05 & 0.10 & - & - & 0.21 \\
\hline & $\mathrm{CK}_{\mathrm{K}}$ & $>151$ & 7.10 & - & - & - & - \\
\hline HCP & & & 0.12 & 0.08 & 0.19 & 0.83 & 0.08 \\
\hline
\end{tabular}

Примечание. Здесь и далее прочерк - показатель не определялся.

Рост гидролитической кислотности и увеличение в составе обменных катионов доли водорода и алюминия (рис. 2) также заметны по уменьшению степени насыщенности почвы основаниями, которое наблюдается в верхних слоях. Так, в пахотном горизонте этот показатель равномерно уменьшается во времени с 76 до 63\%, в переходном элювиально-иллювиальном - с 90 до $82 \%$, а в гор. В1 - с 93.5 до $88.5 \%$.

Изменение условий увлажнения, прогревания и использования почв также влияет на процессы накопления и минерализации органического вещества.

Являясь источником питательных вешеств для растений и одновременно фактором структурообразования, органические вещества почвы вместе с тем определяют ее физические и физико-химические свойства, в частности обменную способность и буферность, регулируют действие избыточной кислотности.

В течение исследуемого периода содержание органического углерода в пахотном горизонте уменьшилось с 1.8 до $1.4 \%$, его запасы в слое 030 см, соответственно, с 77.8 до 58.7 т/га, что в энергетическом эквиваленте означает потерю 9909.5 млн ккал/га. При этом наблюдается увеличение содержания углерода в подпахотном гор. А2В с $0.7 \%$ на момент закладки опыта до $1.2 \%$ по состоянию на 2010 г. (табл. 3). В целом запасы в слое 0-100 см в течение 1961-2010 гг. существенно не изменились.

Длительное окультуривание, внесение в почву органических и минеральных удобрений существенно влияют не только на питательный режим почвы, но и на ее физико-химические свойства. Как отмечалось выше, использование темно-серой оподзоленной почвы наиболее существенно отразилось на ее кислотности, вместе с тем заметны различия и между вариантами опыта (табл. 4). Так, по сравнению с контрольным вариантом (обработка без использования удобрений в течение 1961-2010 гг.) в вариантах, где были введены севообороты с минеральным (разр. 2) и органо-минеральным (разр. 3) удобрениями, значения $\mathrm{pH}$ солевой вытяжки в пахотном горизонте были меньше на 5.1 и $10.2 \%$, соответственно. При сравнении контрольного варианта и варианта с органо-минеральной системой удобрения аналогичную закономерность можно наблюдать и в нижних слоях, в то время как в варианте с минеральным удобрением значение $\mathrm{pH}$ солевой вытяжки больше контрольных, начиная с подпахотного горизонта.

В целом по всем вариантам отмечается изменение реакции почвенного раствора вниз по профилю от слабокислой до нейтральной, при этом заметна четкая приуроченность линии ее перехода к линии вскипания карбонатов. Карбонаты 
Таблица 3. Изменение свойств темно-серой почвы за 1961-2010 гг. Вариант без внесения удобрений

\begin{tabular}{|c|c|c|c|c|c|c|c|}
\hline \multirow[t]{2}{*}{ Год } & \multirow[t]{2}{*}{ Горизонт } & \multirow[t]{2}{*}{ Глубина, см } & \multirow[t]{2}{*}{ pH солевой } & Н гидр & $\begin{array}{c}\text { Сумма } \\
\text { поглощенных } \\
\text { оснований }\end{array}$ & $\begin{array}{c}\text { Степень } \\
\text { насыщенности } \\
\text { основаниями }\end{array}$ & С орг \\
\hline & & & & \multicolumn{2}{|c|}{ смоль(эКв)/КГ } & \multicolumn{2}{|l|}{$\%$} \\
\hline \multirow[t]{5}{*}{1961} & $\mathrm{~A} 1 \mathrm{~A} 2$ & $0-35$ & 5.42 & 2.75 & 8.71 & 76.0 & 1.79 \\
\hline & $\mathrm{A} 2 \mathrm{~B}$ & $36-70$ & 5.54 & 1.25 & 10.89 & 89.7 & 0.71 \\
\hline & B1 & $71-130$ & 5.73 & 0.68 & 9.70 & 93.5 & 0.48 \\
\hline & $\mathrm{B} 2 \mathrm{CK}_{\mathrm{K}}$ & $131-150$ & 6.94 & 0.11 & - & - & 0.28 \\
\hline & $\mathrm{CK}_{\mathrm{K}}$ & $>150$ & 7.01 & - & - & - & - \\
\hline \multirow[t]{5}{*}{1972} & А пах & $0-30$ & 5.33 & 2.96 & 9.05 & 75.4 & 1.50 \\
\hline & A2B & $31-62$ & 5.81 & 2.12 & 10.10 & 82.7 & 0.88 \\
\hline & B1 & $63-105$ & 6.14 & 0.96 & 10.70 & 91.8 & 0.29 \\
\hline & $\mathrm{B} 2 \mathrm{CK}_{\mathrm{K}}$ & $106-145$ & 7.23 & 0.18 & - & - & - \\
\hline & $\mathrm{CK}_{\mathrm{K}}$ & $>145$ & 7.46 & - & - & - & - \\
\hline \multirow[t]{5}{*}{2001} & А пах & $0-32$ & 4.61 & 3.39 & 6.20 & 64.7 & 1.53 \\
\hline & $\mathrm{A} 2 \mathrm{~B}$ & $33-70$ & 5.10 & 1.14 & 7.81 & 87.3 & - \\
\hline & B1 & $71-128$ & 6.04 & 0.68 & 7.95 & 92.1 & - \\
\hline & $\mathrm{B} 2 \mathrm{CK}$ & $129-150$ & 7.02 & - & - & - & - \\
\hline & $\mathrm{CK}_{\mathrm{K}}$ & $>150$ & 7.21 & - & - & - & - \\
\hline \multirow[t]{5}{*}{2010} & А пах & $0-33$ & 4.54 & 5.59 & 9.50 & 62.9 & 1.35 \\
\hline & $\mathrm{A} 2 \mathrm{~B}$ & $34-72$ & 5.43 & 2.39 & 10.97 & 82.1 & 1.22 \\
\hline & B1 & $73-130$ & 5.67 & 1.43 & 11.03 & 88.5 & 0.45 \\
\hline & $\mathrm{B} 2 \mathrm{CK}_{\mathrm{K}}$ & $131-150$ & 7.32 & 0.25 & - & - & 0.29 \\
\hline & $\mathrm{CK}_{\mathrm{K}}$ & $>150$ & 7.41 & - & - & - & - \\
\hline
\end{tabular}

кальция, которые подтягиваются капиллярными силами вверх по профилю, нейтрализуют катионы $\mathrm{H}^{+}$, что объясняет незначительное повышение pH в нижних горизонтах. Применение же минеральных удобрений способствовало большему подкислению почвенного раствора, в результате чего наблюдается меньшее значение этого показателя в верхних слоях на удобряемых вариантах.

Аналогичную закономерность можно наблюдать и для гидролитической и обменной кислотности. Оба вида кислотности имеют повышенные значения в пахотном горизонте и резко уменьшаются вниз по профилю на всех вариантах. При этом минимальные значения в пахотном слое наблюдаются на контрольном варианте, применение минерального и органо-минерального удобрений способствовало увеличению гидролитической кислотности относительно контрольного варианта на 20 и 9.5\%, обменной - на 39 и 33\% соответственно. Таким образом, длительное сельскохозяйственное использование почв способствует увеличению кислотности, и использование удобрений усиливает эту тенденцию.

Сумма обменных оснований в пахотном горизонте в течение исследуемого периода существен- но не изменилась, в нижних слоях наблюдается незначительный ее прирост, вероятно обусловленный миграцией катионов кальция и магния.

Длительное использование почвы привело к существенному уменьшению степени ее насыщенности основаниями. Так, в пахотном горизонте, в зависимости от варианта удобрения, значение этого показателя составляет от 58.8 до $62.9 \%$, в то время как на момент закладки опыта составляло в среднем 76.5\%, более резкое его уменьшение наблюдается на вариантах, где применялись удобрения. Вместе с тем, в нижних горизонтах почвы наблюдается увеличение степени насыщенности основаниями, параллельно поднятию линии вскипания карбонатов.

Анализируя эволюционные изменения почв под влиянием длительного применения удобрений, особое место следует уделять показателям гумусового состояния почв, поскольку в формировании плодородия ведущая роль принадлежит органическим веществам почв, которые определяют весь комплекс их агрофизических, физикохимических и биологических свойств [13].

Динамика содержания органического углерода на различных вариантах многолетнего опыта 


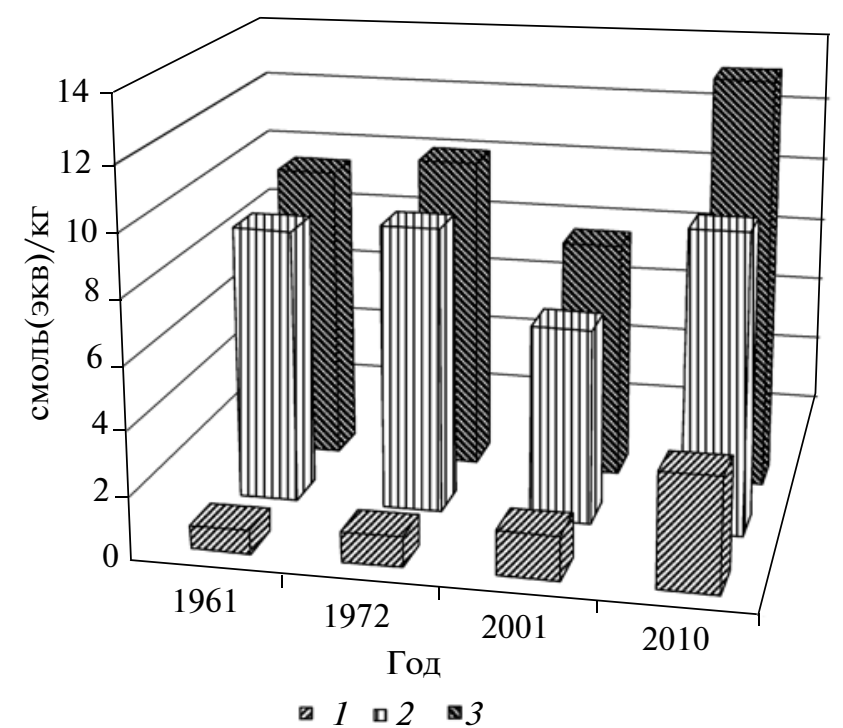

Рис. 2. Изменение гидролитической кислотности (1), суммы поглощенных оснований (2) и емкости поглощения (3) в пахотном горизонте темно-серой почвы, смоль(экв)/кг.

показывает, что в целом длительное использование почвы способствовало уменьшению его содержания в пахотном слое, в то время как применение удобрений частично нивелирует эту негативную тенденцию. Так, если на контроле относительное уменьшение содержания С орг в пахотном горизонте составило $32.5 \%$, то на вари- антах с минеральным и органо-минеральным удобрениями - 28.7 и $19.8 \%$ соответственно. В то же время запасы в слое 0-100 см на варианте с комбинированной системой удобрения увеличились ориентировочно на 20 т/га. Следует также учитывать факт общего увеличения влагообеспеченности территории, что также могло спровоцировать ускоренную минерализацию органических веществ [18].

Сравнение данных эволюции агрохимических и физико-химических показателей темно-серой оподзоленной почвы при длительном сельскохозяйственном использовании при отсутствии удобрения и в условиях минерального и комбинированного органо-минерального удобрения показало, что во всех случаях это провоцирует агрохимическую деградацию, в результате чего пригодность почвы для интенсивного использования ухудшается. Однако в разных условиях степень проявления и направленность процессов разные. Если при использовании почв без внесения удобрений наблюдается резкое уменьшение содержания органического углерода, подкисление почвенного раствора, уменьшение степени насыщенности почвы основаниями, то при применении удобрений потери углерода проявляются менее интенсивно, но процессы, связанные с увеличением кислотности и уменьшением насыщенности почвы основаниями усиливаются.

В то же время резкое уменьшение показателя $\mathrm{pH}$ солевой вытяжки, увеличение гидролитиче-

Таблица 4. Характеристика разрезов, 2010 г.

\begin{tabular}{|c|c|c|c|c|c|c|c|}
\hline Разрез & Горизонт & $\begin{array}{l}\text { Глубина, } \\
\text { см }\end{array}$ & $\begin{array}{l}\text { pH солевой/ } \\
\text { pН водный }\end{array}$ & $\begin{array}{l}\text { Н гидр/Н обм, } \\
\text { смоль(эКв)/Кг }\end{array}$ & $\begin{array}{c}\text { Сумма } \\
\text { поглощенных } \\
\text { оснований, } \\
\text { смоль(эКв)/кг }\end{array}$ & $\begin{array}{c}\text { Степень } \\
\text { насыщенности } \\
\text { основаниями, } \\
\%\end{array}$ & $\begin{array}{c}\text { C орг, } \\
\%\end{array}$ \\
\hline \multirow[t]{5}{*}{1} & А пах & $0-33$ & $4.54 / 5.62$ & $5.59 / 0.41$ & 9.50 & 62.9 & 1.35 \\
\hline & A2B & $34-72$ & $5.43 / 6.73$ & $2.39 / 0.18$ & 10.97 & 82.1 & 1.22 \\
\hline & $\mathrm{B} 1$ & $73-130$ & $5.67 / 7.17$ & $1.43 / 0.15$ & 11.03 & 88.5 & 0.45 \\
\hline & $\mathrm{B} 2 \mathrm{CK}_{\mathrm{K}}$ & $131-150$ & $7.32 / 7.84$ & $0.25 /-$ & - & - & 0.29 \\
\hline & $\mathrm{CK}_{\mathrm{K}}$ & $>150$ & $7.41 / 8.25$ & - & - & - & - \\
\hline \multirow[t]{5}{*}{2} & А пах & $0-34$ & $4.32 / 5.53$ & $6.94 / 0.67$ & 9.92 & 58.8 & 1.39 \\
\hline & $\mathrm{A} 2 \mathrm{~B}$ & $35-81$ & $6.14 / 7.61$ & $1.60 / 0.26$ & 11.52 & 87.8 & 1.02 \\
\hline & B1 & $82-135$ & $6.85 / 7.95$ & $0.95 / 0.20$ & 11.68 & 92.5 & 0.45 \\
\hline & B2CK & $136-168$ & $7.58 / 8.32$ & $0.22 /-$ & - & - & 0.31 \\
\hline & $\mathrm{CK}_{\mathrm{K}}$ & $>168$ & $7.77 / 8.51$ & - & - & - & - \\
\hline \multirow[t]{5}{*}{3} & А пах & $0-37$ & $4.12 / 5.39$ & $6.15 / 0.61$ & 9.45 & 60.6 & 1.49 \\
\hline & $\mathrm{A} 2 \mathrm{~B}$ & $38-80$ & $5.36 / 6.65$ & $1.78 / 0.28$ & 10.72 & 85.8 & 1.17 \\
\hline & B1 & $81-134$ & $5.73 / 6.94$ & $1.40 / 0.09$ & 11.15 & 88.8 & 0.47 \\
\hline & $\mathrm{B} 2 \mathrm{CK}$ & $135-160$ & $6.61 / 7.56$ & $0.15 /-$ & - & - & 0.26 \\
\hline & $\mathrm{CK}_{\mathrm{K}}$ & $>160$ & $7.23 / 8.12$ & - & - & - & - \\
\hline НСР & & & $0.05 / 0.04$ & $0.08 / 0.03$ & 0.09 & 0.51 & 0.05 \\
\hline
\end{tabular}


ской и обменной кислотности в верхних горизонтах, возможно, вызвано не только антропогенным использованием почв, но и изменениями климатического и агроэкологического состояния почв зоны в целом вследствие повышения теплои влагообеспеченности территории [5]. Поднятие уровня грунтовых вод, в свою очередь, вызвало повышение капиллярной каймы и линии вскипания карбонатов вследствие их подтягивания капиллярными силами. Сочетание этих процессов объясняет деградационные изменения верхних горизонтов (уменьшение значений рН солевой и водной вытяжек, увеличение гидролитической кислотности, уменьшение степени насыщенности основаниями) и изменения в нижних слоях почвы - увеличение $\mathrm{pH}$, степени насыщенности основаниями, незначительное увеличение емкости катионного обмена, поднятие линии вскипания карбонатов.

\section{ЗАКЛЮЧЕНИЕ}

Исследование почвенных разрезов темно-серой почвы в условиях полевого опыта показало, что по вариантам опыта существенных изменений в генетическом строении почвы за период сельскохозяйственного использования не произошло.

В течении периода наблюдений (1961-2010 гг.) темно-серая оподзоленная почва подверглась изменениям практически по всем исследуемым показателям - в верхнем горизонте существенно уменьшились значения рН солевой и водной вытяжек, увеличились гидролитическая и обменная кислотности, уменьшились показатели степени насыщенности почвы основаниями и содержания органического углерода. В нижних горизонтах в незначительной степени возросли значения pH, емкости катионного обмена и степени насыщенности основаниями. Поднялась линия вскипания карбонатов.

Сравнительный анализ почв, которые в течение 1961-2010 гг. находились в разных условиях использования, показал, что применение удобрений влияет на характер изменений темно-серой оподзоленной почвы. Так, минеральные удобрения усиливают процесс подкисления почвенного раствора, способствуют уменьшению насыщенности почвы основаниями, мало влияя на динамику содержания органических веществ. Применение в комплексе минеральных и органических удобрений усиливает вышеуказанные негативные изменения по сравнению с контролем, но дает лучший эффект по сравнению с минеральной системой удобрения. Кроме того, внесение органических удобрений значительно уменьшает потери органического углерода в пахотном слое почвы и способствует незначительной его аккумуляции в слое $0-100 \mathrm{~cm}$.

\section{СПИСОК ЛИТЕРАТУРЫ}

1. Александрова Л.Н. Органическое вещество почвы и процессы его трансформации. Л.: Наука, 1980. $287 \mathrm{c}$.

2. Александровский А.Л., Александровская Е.И. Эволюция почв и географическая среда. М.: Наука, 2005.

3. Андреева В.M. Длительное применение минеральных удобрений // Химизация сельского хозяйства. 1989. № 12. С. 49-52.

4. Веремеєнко C.I. Еволюція та управління продуктивністю грунтів Полісся України. Луцьк, 1997.

5. Веремеєнко С.I., Фурманець О.А. Оцінка гідротермічного режиму темно-сірих грунтів Західного Лісостепу України // Вісник ХНАУ. 2011. № 2.

6. Власюк П.А., Городній М.М. Агрохімія. К.: Вища школа, 1975. $168 \mathrm{c}$.

7. Дегтярьов В.В. Гумус чорноземів лісостепу і степу України. Харьков: Майдан, 2011.

8. Зайдельман Ф.Р. Деградация почв как результат антропогенной трансформации их водного режима и защитные мероприятия // Почвоведение. 2009. № 1. С. 93-105.

9. Кузнецова И.В., Уткаева В.Ф., Бондарев А.Г. Оценка изменения физических свойств пахотных дерново-подзолистых суглинистых почв нечерноземной зоны России в зависимости от характера антропогенного воздействия // Почвоведение. 2009. № 2. С. $152-162$.

10. Левин Ф.И., Денисова Е.А. Изменение гумусового состояния дерново-подзолистой почвы при внесении удобрений // Вестник МГУ. Сер. почвоведение. 1987. № 3. С. 48-52.

11. Лукьянчикова 3.И. Содержание и состав гумуса в почвах при интенсивном земледелии // Почвоведение. 1980. № 6. С. 78-80.

12. Надточій П.П., Трембіцький В.А. Кислотно-основна буферність і проблема вапнування кислих грунтів Полісся: актуальні питання агроекології // Вісник ДАУ. 2003. № 2. С. 3-17.

13. Польовий B.M. Оптимізація систем удобрення у сучасному землеробстві. Рівне: Волинські обереги, 2007.

14. Почвы Украины и повышение их плодородия / Под ред. Носко Б.С., Медведева В.В., Трускавецкого Р.С., Чесняка Г.Я. К.: Урожай, 1988. 176 с.

15. Прокопович В.Н. Изменение физических свойств дерново-подзолистой легкосуглинистой почвы в связи с длительным применением различных систем удобрения// Докл. ТСХА. 1979. Вып. 248. C. 107-111.

16. Тараріко О.Г. Охорона і відтворення родючості грунтів - запорука сталого розвитку аграрних виробничих систем України // Матеріали міжнародної конференції "Сталий розвиток агроекосистем”. Вінниця, 2002. С. 10-14.

17. Таргульян В.О. Процессы почвообразования и эволюция почв. М., 1985.

18. Тулина А.С., Семенов В.М., Розанова Л.Н., Кузнецова Т.В., Семенова Н.А. Влияние влажности на стабильность органического вещества почв и 
растительных остатков // Почвоведение. 2009. № 11. C. $1333-1340$.

19. Уткаева В.Ф., Сквориова Е.Б. Изменение агрофизических свойств пойм при различных антропогенных нагрузках // Почвоведение. 2009. № 2. C. $167-177$.

20. Филон И.И., Шеларь И.А. Влияние длительного применения удобрений на физико-химические свойства темно-серой почвы и подвижность в ней ионов алюминия // Агрохимия. 2001. № 4. С. 5-9.

21. Шикула М.К., Сенчук С.М. Шляхи відтворення родючості грунтів // Агрохімія і грунтознавство. Харків, 2002. Кн. 3. С. 168-169.
22. Чендев Ю.Г. Антропогенная эволюция серых лесостепных почв южной части среднерусской возвышенности // Почвоведение. 2011. № 1. С. 3-15.

23. Sara J. Scherr. Soil Degradation: A Threat to Developing-country Food Security by 2020. International food policy research institute. Washington, 1999. P. 9-25.

24. Stocking M., Peake L. Erosion loss in soil productivity: Trends in Research and international cooperation. FAO and Overseas Development group. University of East Anglia, Rome and Norwich, U.K., 1985.

25. Tiffen M., Mortimore M. More people, less erosion: Environmental recovery in Kenya. Chichester, U.K., 1994. 